\title{
Bio-Geo-Chemical Characterization of Bangladeshi Textile Effluents
}

\author{
Farjana Ahmed, Abdul Alim, Fahmida Alam, Tahsina Islam, Ali Azam Talukder* \\ Department of Microbiology, Jahangirnagar University, Dhaka, Bangladesh \\ Email: ${ }^{*}$ aat@juniv.edu, tunubj@yahoo.com
}

Received 20 March 2015; accepted 11 May 2015; published 14 May 2015

Copyright (C 2015 by authors and Scientific Research Publishing Inc.

This work is licensed under the Creative Commons Attribution International License (CC BY).

http://creativecommons.org/licenses/by/4.0/

(c) (i) Open Access

\begin{abstract}
Recently industrialization has become one of the most promising contributors for economic development of Bangladesh. However, at the same time, industrial pollution has turned into one of the major problems for human being as well as for the environment. In order to understand the effect of textile effluent (TE) on environmental pollution, TE samples collected from North-west part of the capital of Bangladesh, Dhaka (Savar, Ashulia and Tongi area) were characterized biologically, biochemically and biophysically. Eight potential microorganisms were isolated (3 bacteria and 5 fungi) from the collected TE and two of them were used to de-colorization of TE significantly by bioremediation process. Among the various parameters checked here, some physicochemical properties like TDS, COD, BOD, DO and heavy metals like Cd and $\mathrm{Cr}$ were detected in quite high amounts. Altogether, our results indicate that TE is one of the serious pollutants, which could damage environment as well as water body severely.
\end{abstract}

\section{Keywords}

Textile Effluent, Bangladesh, Pollution, Heavy Metals, BOD, COD

\section{Introduction}

Textile industries are considered as the key industrial sectors of Bangladesh as $78 \%$ of the total export earning comes from textile and textile related goods contributing $12 \%$ to GDP [1]. There are many hazardous and potentially dangerous polluting industries situated in the cities of Bangladesh [2]. Textile industries release huge amount of effluents to aquatic systems, which contain toxic and hazardous pollutants degrading the environment [3] [4]. The major chemical pollutants present on textile effluents are dyes containing carcinogenic amines, toxic heavy metals, pentachlorophenol, chlorine bleaching, halogen carriers, free formaldehyde, biocides, fire retar-

"Corresponding author. 
dants and softeners [5] [6]. Approximately, 10,000 different dyes and pigments are used industrially and over $0.7-0.8$ million tons of synthetic dyes are produced annually worldwide amongst which $10 \%-15 \%$ of the dyes are released into the environment [7] [8].

Textile effluents (TE) are highly responsible for organ damages, disorders in the respiratory tract, dysfunction of the heart, disorders in the nervous system, skin diseases, abnormalities in fertility and pregnancy. Besides the effects on human health, high concentrations of heavy metals in textile wastewater have a negative impact on the environment and water quality itself as well as on the biota living in the water bodies [9]. Now-a-days different standards are used to indicate the maximum permissible values of the toxic materials found in TE. According to permissive standard of TE, textile materials must fulfill high ecological requirements in low concentrations of allergenic, toxic and carcinogenic metals.

It has been reported that many bacterial and fungal species have the ability to decolorize and detoxify TEs by enzymatic degradation of organic materials through the process of bioremediation [10]. Remove various dyes from textile effluents are usually done by expensive physicochemical processes [11]. On the other hand, biological treatment based microbial transformation of textile dyes is natural, cheap and more efficient way of effluent treatment [12]. The objective of this study was characterizing the TEs, isolating microorganisms from collected TEs and determining their effects to decrease various TE toxic components through bio-remediation processes.

\section{Materials and Methods}

\subsection{Sample Collection}

Textile effluents (TE) samples were collected from three northern industrial parts of Dhaka, Bangladesh. The zones were: Savar (Pakiza textile industry), Ashulia [Dhaka export processing zone (DEPZ)] and Tongi textile area. Two TE samples (sample 1 and sample 2) were collected from each of the three areas. Sample 1s were collected from the effluent discharge pipes of the industries, whereas, sample $2 \mathrm{~s}$ were collected from the water bodies adjacent to the discharge points. The initial $\mathrm{pH}$ and temperature of effluent samples were determined and noted down immediately at the sampling site. All these samples were transported to the laboratory in an icepacked chest box. Collected samples were stored at $4^{\circ} \mathrm{C}$ until further use.

\subsection{Isolation of Microorganism from TEs}

As Nutrient and YEPD [Yeast Extract (1.0\%) Peptone (2.0\%) Dextrose (2.0\%)] Agar are the basal media (at pH 5.0) for screening of bacteria and fungi respectively, the diluted (up to 10 folds) TE samples were screened for the presence of bacteria and fungi on those media by following the method described by Barragán et al. [13]. 10 $\mu \mathrm{l}$ of Sample 1 and $100 \mu \mathrm{l}$ of sample 2 were spread both over the Nutrient and YEPD Agar plates and incubated both at $37^{\circ} \mathrm{C}$ and $42^{\circ} \mathrm{C}$ for 24 hours. The plates were also screened for viable colony count.

\subsection{Microbial Treatment of TE}

After 24 hours of incubation, among all the eight microbial colonies only two colonies (S2A, S2B) were selected on the basis of highest growth activity for observing the effects of $\mathrm{pH}$ and temperature on TE de-colorization. The Mac-Cartney bottles containing different effluent samples were incubated for 1 - 7 days together with two different inoculums (S2A, S2B) both at $37^{\circ} \mathrm{C}$ and at $42^{\circ} \mathrm{C}$ for checking the decolonization effect as well as the reduction of $\mathrm{pH}$ from TE by bioremediation process by following methods of Idris et al. [14]. Sterile internal negative (distilled water) and positive controls (TE without inoculums) were also maintained under the same condition.

\subsection{Physicochemical Characterization of the TEs}

The physicochemical properties such as Biological Oxygen Demand (BOD), Chemical Oxygen Demand (COD), Electrochemical Conductivity (EC), Total Dissolved Solids (TDS), Total Suspended Solid (TSS), Dissolved Oxygen (DO) and four most commonly persistent heavy metal components content ( $\mathrm{Zn}, \mathrm{Cu}, \mathrm{Cd}$ and $\mathrm{Cr}$ ) was estimated by the standard method developed by Huq et al. [15]. In case of heavy metal estimation, standard concentration for $\mathrm{Zn}, \mathrm{Cd}, \mathrm{Cu}$ and $\mathrm{Cr}$ were followed as 3.0, 0.003, 2.0 and $0.05 \mathrm{ppm}$ respectively according to the 
WHO standards.

\section{Results and Discussion}

Bangladesh is the second largest ready-made garments manufacturer country in the world. The money earned from exporting textiles is the single greatest source of economic growth of Bangladesh. These large numbers of textile industries discharge a huge amount of textile effluents everyday without proper treatment, which contain huge amount of toxic dyes and other chemical toxic substances that are poisonous for not only human, but also other creatures in this planet, including both the aquatic and the terrestrial environment [16]. This study, we have tried to characterize TEs under various treatments and conditions as shown below.

\subsection{Sample Collection}

Textile effluents (TE) samples were collected from three northern industrial parts of Dhaka, the capital of Bangladesh. The three sampling zones were selected which were located at Savar, Ashulia and Tongi textile area are shown in Figure 1. In each of 3-sampling locations, we have collected two samples. Total six samples were collected and their detail sample collection, transportation and preservation procedures were described in detail in the Materials and Methods. TE samples were characterized further in different treatments and conditions as described below.

\subsection{Biological Characterization of TEs}

Various collected samples were diluted where necessary, spread on agar media and then incubated at 37 and $42^{\circ} \mathrm{C}$ for 24 hours. Three $(\mathrm{C} 1, \mathrm{C} 2$ and $\mathrm{C} 3)$ different discrete colonies $\left(3.5 \times 10^{8}\right.$ colonies $\left./ \mathrm{ml}\right)$ were found on nutrient agar plates which were considered as bacteria and five (C4, C5, C6, S2A and S2B) discrete colonies (2.5 $\times$ $10^{8}$ colonies $/ \mathrm{ml}$ ) were found on YEPD plate which were considered as fungi based on their growth in selective media. The screening of microorganisms in Nutrient Agar and YEPD from the TEs are shown in Figure 2. All the eight colonies were categorized based on their morphology, growth physiology, pigmentation followed by gram reaction and microscopic observation. Selected colonies were further analyzed and sub-cultured to maintain pure culture and stored. The Biological characterization of isolated microorganisms is shown in Table 1 for further characterization.

\subsection{Physicochemical Characterization of the TE}

The effluent samples collected from the textile areas were blue in color, which indicate that TEs are not treated properly before release them from the industry. Because, they were pungent in smell and their initial $\mathrm{pH}$ during sample collection were around 10.0 and the temperature range of those samples was $31^{\circ} \mathrm{C}$ to $35^{\circ} \mathrm{C}$. Therefore, we have decided to check the various physicochemical parameters like EC, TDS, TSS, DO, BOD, COD contents on TEs samples. The results are illustrated in Figure 3.

We also have checked whether TEs contain heavy metals or not. TEs sample collection and preparation for the

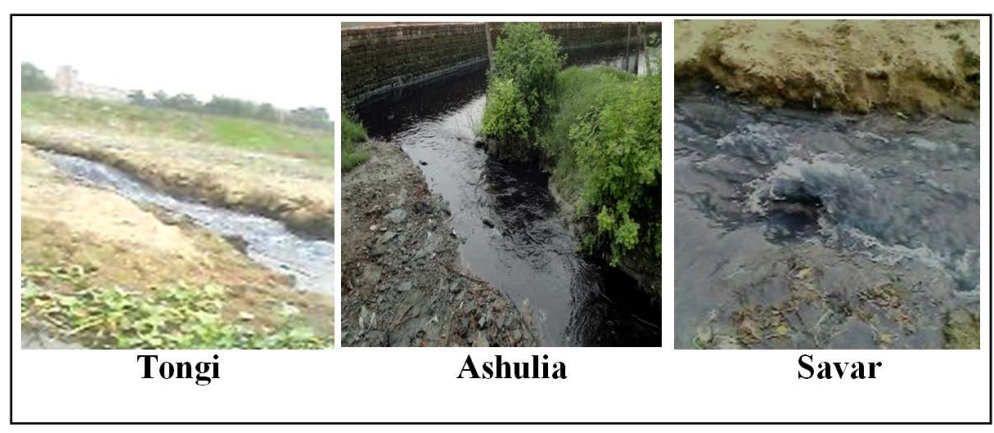

Figure 1. Location of TEs sample-1 collection sites. Three different zones were selected (Tongi textile area [left] Ashulia [middle] and Savar [right]) for the collection of TEs sample. 

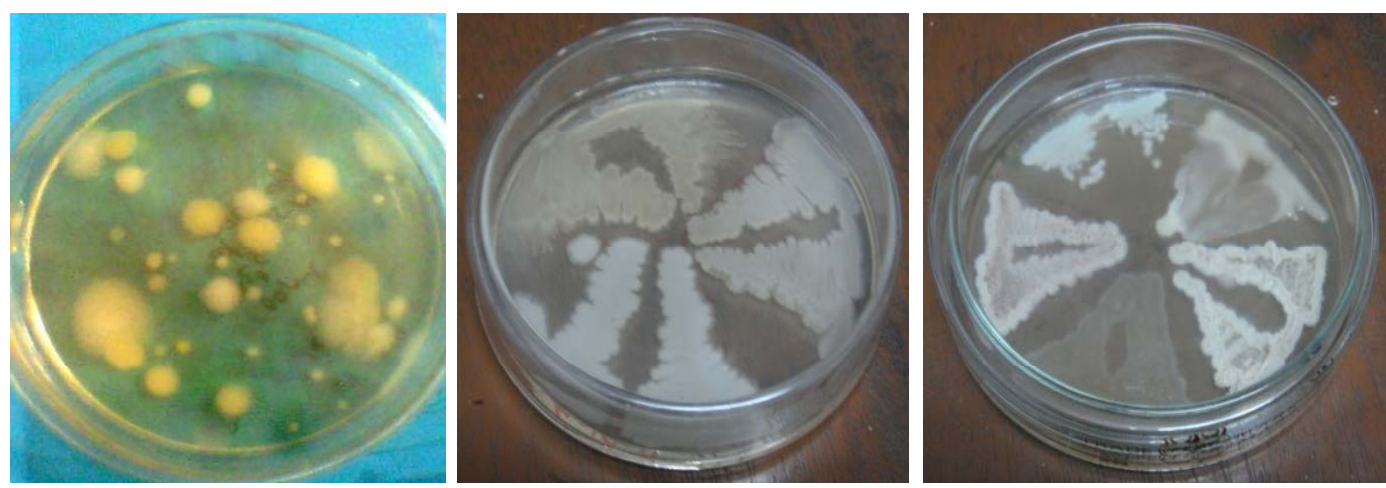

Figure 2. Screening of various microorganisms in Nutrient Agar (left most) and YEPD (rest of 2 right images) plates. Various TE samples were diluted where necessary and various concentrations (10 $\mu$ l of sample 1 and $100 \mu \mathrm{l}$ of sample 2) were spread both over the Nutrient and YEPD Agar [Yeast Extract (1.0\%), Peptone (2.0\%), Dextrose $(2.0 \%)$ at $\mathrm{pH} 5.0$ ] plates and incubated both at $37^{\circ} \mathrm{C}$ or $42^{\circ} \mathrm{C}$ for 24 hours. Different type of microorganisms are seen which were characterized further under various treatments and conditions.

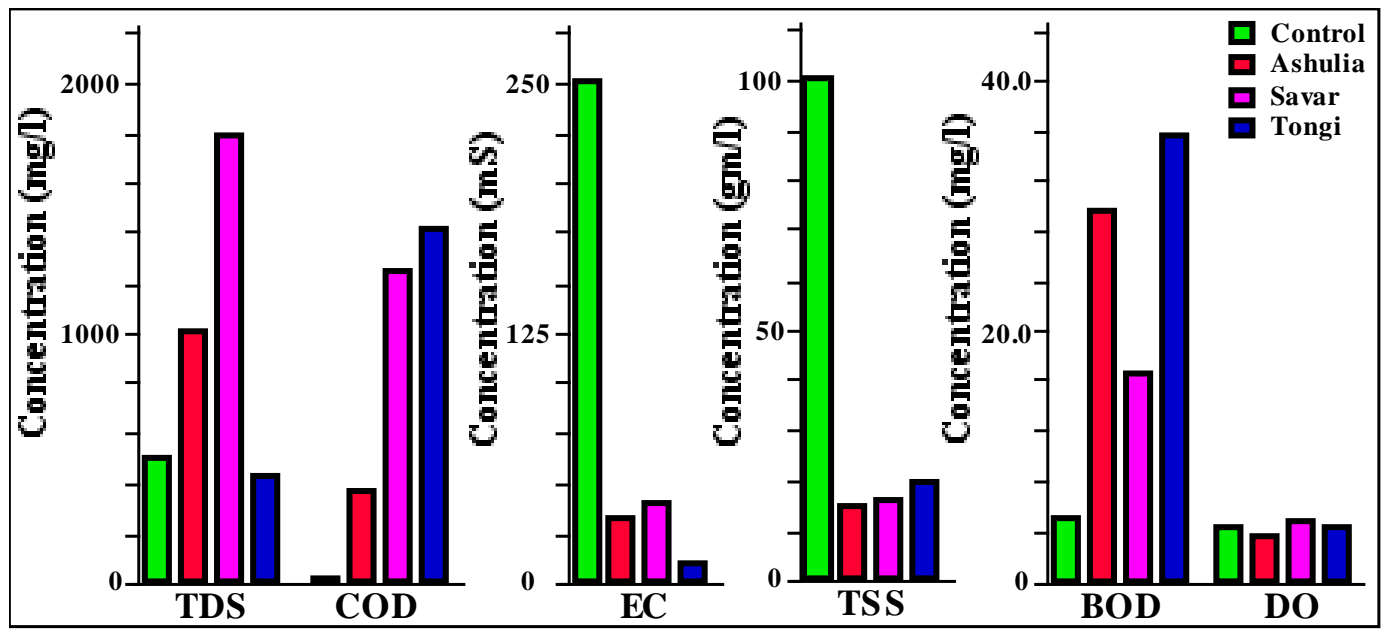

Figure 3. Various physicochemical parameters of TEs collected from three different sites of Bangladesh, where textile industries are available. Various parameters like TDS, COD, EC, TSS, BOD and DO were estimated from TEs are shown. Detail experimental procedure and conditions are explained in Materials and Methods.

Table 1. Biological characterization of TE.

\begin{tabular}{|c|c|c|c|c|}
\hline Strain code & Colony color, shape/size and growth & Gram staining & Microscopic view & Microorganism \\
\hline C1 & $\begin{array}{l}\text { Yellow, } 0.7-1.3 \mathrm{~cm} \text { in diameter, } \\
\text { rapid growth }\end{array}$ & Gram Negative & Rod shaped & Bacteria \\
\hline C2 & $\begin{array}{l}\text { Of White, } 0.2-0.4 \mathrm{~cm} \text { in diameter, } \\
\text { slow growth }\end{array}$ & Gram Positive & Oval shaped & Bacteria \\
\hline C3 & White, $0.5-0.7 \mathrm{~cm}$ in diameter, rapid growth & Gram Negative & Rod shaped & Bacteria \\
\hline C4 & Red, raised, jelly like round colony & ND & Oval shaped & Fungi \\
\hline C5 & White, round oily colony & ND & Oval shaped & Fungi \\
\hline C6 & Of white oily, raised colony & ND & Rod shaped & Fungi \\
\hline S2A & White, raised, jelly like colony & ND & Oval shaped & Fungi \\
\hline S2B & Yellow, raised colony & ND & Oval shaped & Fungi \\
\hline
\end{tabular}

$\mathrm{ND}=$ Not Determined. 
detection of heavy metals content are explain in detail in the Materials and Methods. The results for the detection of heavy metals are shown in Figure 4 and Table 2. Among the estimated heavy metal concentrations, $\mathrm{Zn}$ and $\mathrm{Cu}$ were found to be within acceptable level in all the three TEs, whereas, $\mathrm{Cr}$ and $\mathrm{Cd}$ levels were found higher than that of permissible WHO standards (Table 2). It is clear that the TE samples collected from Savar and Tongi areas contain higher amount of heavy metals ( $\mathrm{Cd}$ and $\mathrm{Cr}$ ) compared to other industrial areas. Since, it has previously been reported that the incidence of weekly intake of cadmium by rice is very high in Bangladesh;
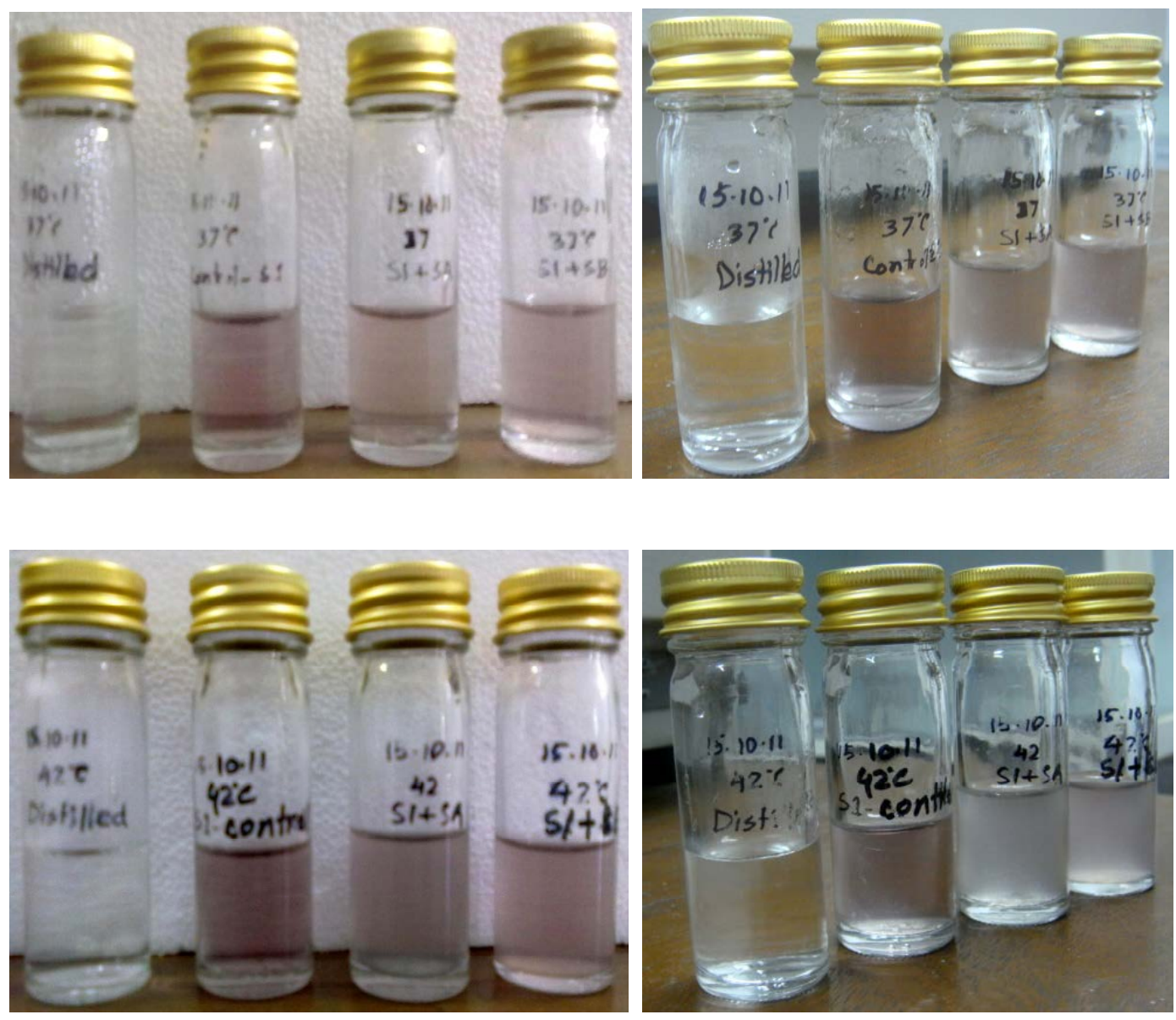

Figure 4. Effect of pHs and temperature on TE de-colorization by bioremediation. Microorganism screening, isolation and preparation for checking the de-colorization effect of TE under different temperatures were explained in detail in the Materials and Methods section. Each of 4-bottols in each panel from left to right represent water sample (negative control), TE sample S1 (positive control), S1 + S2A and S1 + S2B. The top left and right, and the bottom left and right panels represent the before and after incubation of various TE samples at $37^{\circ} \mathrm{C}$ and $42^{\circ} \mathrm{C}$, respectively, for 7-days.

Table 2. Detection of heavy metals in TE samples.

\begin{tabular}{cccccc}
\hline & \multicolumn{5}{l}{ Heavy metals content (ppm) in TEs } \\
\cline { 3 - 5 } & Zn & Cd & Cu & Cr \\
\hline Standard & 3.0 & 0.003 & 2.00 & 0.05 \\
Ashulia & 0.6 & 0.004 & 0.30 & 0.10 & 0.20 \\
Savar & 1.4 & 0.005 & 0.10 & 0.05 & 0.15 \\
Tongi & 0.8 & 0.005 & & & \\
\hline
\end{tabular}


such incidence may cause serious health problems in near future [17]. Analysis of physicochemical parameters revealed that the EC and TSS were within normal level (Figure 3). Whereas, high level of TDS, BOD and COD revealed high load of pollution incidence, which may result metabolic alkalosis, damage to the heart muscle and the soil infertility affecting plant and animal life severely [18] [19]. If COD level increases due to organic effluents, atmospheric $\mathrm{O}_{2}$ cannot diffuse through water body. Therefore, the dissolved oxygen level decreases dramatically, which causes death of various aquatic flora and fauna [20]. Low COD generally leads to hypoxia that causes reduced cell functioning, disrupts circulatory fluid balance in aquatic species causing even death of individual organism [21]. Analysis of heavy metal exhibits the presence of excess amounts of chromium and cadmium in the textile effluents. This result clearly indicates the presence of such metal ions in the dyes used in the textile industry, which is not further being treated during the disposal to the aquatic environment. Several water bodies, including rivers, canals, estuaries containing excess amount of chromium and cadmium can contaminate surrounding land; either through irrigation for agricultural purposes, dumping of dredged sediments or flooding and can transport heavy metals for considerable distances, even up to $50 \mathrm{~km}$, from the origin where those metals are used for industrial benefits. The huge amount of Cd entering into the fresh water from the TE may rapidly be absorbed by plant and animal which causing various type of diseases. Ingestion of any significant amount of cadmium causes immediate poisoning, damage to the liver/kidneys and also has carcinogenic effect [16].

\subsection{Effect of $\mathrm{pH}$ and Temperatures on TE De-Colorization by Bioremediation}

After incubating the TE samples for 7 days both at $37^{\circ} \mathrm{C}$ and $42^{\circ} \mathrm{C}$ with two strains, significant de-colorization effect was observed. These changes were absent when compared TE with the color and $\mathrm{pH}$ of internal control (Figure 3). The color change was due to the presence of dyes in TE in association with a dramatic reduction of sample $\mathrm{pH}$. The initial average $\mathrm{pH}(10.0)$ of the TE samples was highly alkaline which can exert numerous toxic effects on the environment as well as on the living creatures. After 7-day incubation, $\mathrm{pH}$ of treated TE samples was detected as low as 7.0, whereas distilled water $\mathrm{pH}$ remained constant and sample without inoculums (positive control) showed some variation in $\mathrm{pH}$ change. The graphical presentation of $\mathrm{pH}$ change is depicted in Figure 5. Among the samples, S2A treated sample showed rapid $\mathrm{pH}$ change which was more significant at $42^{\circ} \mathrm{C}$ than that at $37^{\circ} \mathrm{C}$. Textile effluents de-colorization effect was also rapid at $42^{\circ} \mathrm{C}$ rather than at $37^{\circ} \mathrm{C}$ (Figure 5). It is clear that temperature has effect on metabolic activity of microorganisms as well as in de-colorization process, because the change of alkaline $\mathrm{pH}$ to neutral $\mathrm{pH}$ by microorganisms assists the de-colorization of TE samples [22] [23].

\section{Acknowledgements}

This research was supported by Ministry of Education (17/10, M-15/2007/226), Bangladesh and the HEQEP
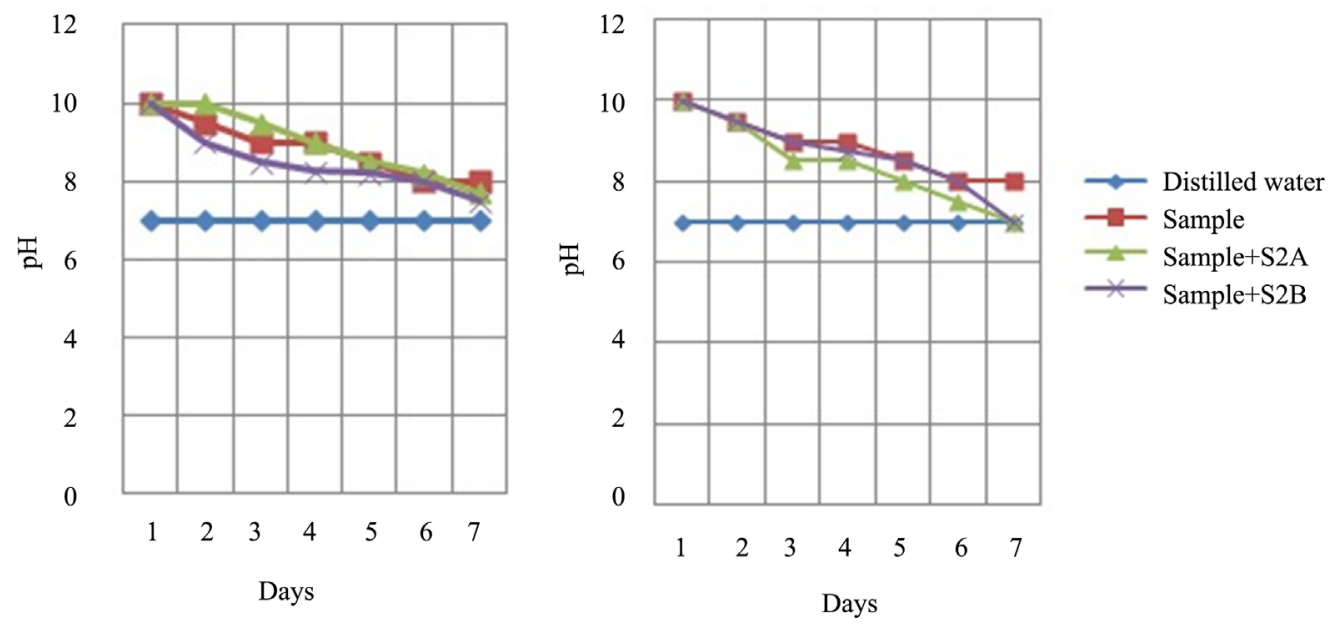

Figure 5. Effect of pHs and temperatures on TE de-colorization by bioremediation process. Textile Effluents pH effect was observed 0.0-to until 7.0-days of incubation either at $37^{\circ} \mathrm{C}$ or at $42^{\circ} \mathrm{C}$ are shown in left and right graph, respectively. Other experimental conditions are shown in detail in Materials and Methods. 
(W1, CP-3413) for publication cost of this manuscript which are hereby gratefully acknowledged.

\section{References}

[1] Bangladesh Textile Mills Association (2012) Annual Report, 14-35.

[2] Alam, K. (2003) Cleanup of the Buriganga River: Integrating the Environment into Decision Making. Murdoch University, Murdoch.

[3] Dubey, A., Mishra, N., Singh, N., Deb, A. and Verma, S. (2010) Isolation of Dye Degrading Microorganism. Electronic Journal of Environmental, Agricultural and Food Chemistry, 9, 1534-1539.

[4] Sharma, D.K., Saini, H.S., Singh, M., Chimni, S.S. and Chadha, B.S. (2004) Isolation and Characterization of Microorganisms Capable of Decolorizing Various Triphenylmethane Dyes. Journal of Basic Microbiology, 44, 59-65. http://dx.doi.org/10.1002/jobm.200310334

[5] Prasad, A.A. and Kvb, R. (2010) Physico Chemical Characterization of Textile Effluent and Screening for Dye Decolorizing Bacteria. Global Journal of Biotechnology and Biochemistry, 5, 80-86.

[6] Zeiner, M., Rezi, I. and Steffan, I. (2007) Analytical Methods for the Determination of Heavy Metals in the Textile Industry. Kem India, 56, 587-595.

[7] Fazli, M.M., Mesdaghinia, A., Naddafi, K., Nasseri, S., Yunesian, M., Assadi, M.M., Rezaie, S. and Hamzehei, H. (2010) Optimization of Reactive Blue 19 Decolorization by Ganoderma sp. Using Response Surface Methodology. Iranian Journal of Environmental Health Science \& Engineering, 7, 35-42.

[8] Park, C., Lim, J.S., Lee, Y., Lee, B., Kim, S.W., Lee, J. and Kim, S. (2007) Optimization and Morphology for Decolorization of Reactive Black 5 by Funalia trogii. Enzyme and Microbial Technology, 40, 1758-1764. http://dx.doi.org/10.1016/j.enzmictec.2006.12.005

[9] Ohe, T., Watanabe, T. and Wakabayashi, K. (2004) Mutagens in Surface Waters: A Review. Mutation Research, 567, 109-149. http://dx.doi.org/10.1016/j.mrrev.2004.08.003

[10] Mahbub, K.R., Mohammad, A., Ahmed, M.M. and Begum, S. (2012) Decolorization of Synthetic Dyes Using Bacteria Isolated from Textile Industry Effluent. Asian Journal of Biotechnology, 4, 129-136. http://dx.doi.org/10.3923/ajbkr.2012.129.136

[11] Mahbub, K., Ferdouse, J. and Anwar, M. (2011) Demonstration of Decolorization of Various Dyes by Some Bacterial Isolates Recovered from Textile Effluents. Bangladesh Journal of Scientific and Industrial Research, 46, 323-328. http://dx.doi.org/10.3329/bjsir.v46i3.9037

[12] Dos Santos, A.B., Cervantes, F.J. and Van Lier, J.B. (2007) Review Paper on Current Technologies for Decolourisation of Textile Wastewaters: Perspectives for Anaerobic Biotechnology. Bioresource Technology, 98, 2369-2385.

[13] Barragán, B.E., Costa, C. and Carmen, M. (2007) Biodegradation of Azo Dyes by Bacteria Inoculated on Solid Media. Dyes and Pigments, 75, 73-81. http://dx.doi.org/10.1016/j.dyepig.2006.05.014

[14] Idris, A., Hashim, R., Rahman, R.A., Ahmad, W., Ibrahim, Z., Razak, P.A., Zin, H.M. and Bakar, I. (2007) Application of Bioremediation Process for Textile Wastewater Treatment Using Pilot Plant. International Journal of Engineering and Technology, 4, 228-234.

[15] Huq, S. and Alam, M. (2005) A Handbook on Analyses of Soil, Plant and Water. BACER-DU, University of Dhaka, Bangladesh.

[16] Moawad, H., El-Rahim, W.M. and Khalafallah, M. (2003) Evaluation of Biotoxicity of Textile Dyes Using Two Bioassays. Journal of Basic Microbiology, 43, 218-229. http://dx.doi.org/10.1002/jobm.200390025

[17] Meharg, A.A., Norton, G., Deacon, C., Williams, P., Adomako, E.E., Price, A., Zhu, Y., Li, G., Zhao, F.J., McGrath, S., Villada, A., Sommella, A., De Silva, P.M., Brammer, H., Dasgupta, T. and Islam, M.R. (2013) Variation in Rice Cadmium Related to Human Exposure. Environmental Science \& Technology, 47, 5613-5618. http://dx.doi.org/10.1021/es400521h

[18] Buckley, C. (1992) Membrane Technology for the Treatment of Dyehouse Effluents. Water Science \& Technology, 25, 203-209.

[19] Knapp, J.S. and Newby, P.S. (1995) The Microbiological Decolorization of an Industrial Effluent Containing a DiazoLinked Chromophore. Water Research, 29, 1807-1809. http://dx.doi.org/10.1016/0043-1354(94)00341-4

[20] Zhou, W.C. and Zimmermann, W. (1993) Decolorization of Industrial Effluents Containing Reactive Dyes by Actinomycetes. FEMS Microbiology Letters, 107, 157-161. http://dx.doi.org/10.1111/j.1574-6968.1993.tb06023.x

[21] Carman, A.L., Timsina, L.R. and Scutchfield, F.D. (2014) Quality Improvement Activities of Local Health Departments during the 2008-2010 Economic Recession. American Journal of Preventive Medicine, 46, 171-174. http://dx.doi.org/10.1016/j.amepre.2013.10.005 
[22] Akdogan, H.A., Topuz, M.C. and Urhan, A.A. (2014) Studies on Decolorization of Reactive Blue 19 Textile Dye by Coprinus plicatilis. Journal of Environmental Health Science \& Engineering, 12, 49. http://dx.doi.org/10.1186/2052-336X-12-49

[23] Arabaci, G. and Usluoglu, A. (2014) The Enzymatic Decolorization of Textile Dyes by the Immobilized Polyphenol Oxidase from Quince Leaves. The Scientific World Journal, 2014, Article ID: 685975. http://dx.doi.org/10.1155/2014/685975 